\title{
Seasonal variations in the effectiveness of urinary chemosignals influencing puberty in female house mice
}

\author{
L. C. Drickamer \\ Biology Department, Williams College, Williamstown, MA 01267, U.S.A.
}

\begin{abstract}
Summary. Three separate experiments tested whether the seasonal variation in the effectiveness for accelerating or delaying puberty in female conspecifics of male urine, urine from pregnant or lactating females, and urine from females housed in groups is attributable to seasonal changes in the quality of the chemosignals released by the donor mice or to seasonal shifts in the sensitivity to the chemosignals for recipient females or to some interaction between these two factors. Six-by-six cross-classified designs were used with urine collection taking place in alternate months for I year and urine treatments with samples from all 6 collection months applied in the same alternate months in the subsequent year. For all three urinary chemosignals the seasonal variations in chemosignal effectiveness were determined to be a function of changes in recipient sensitivity and not of any seasonal shifts in the chemosignals released by donor mice. Seasonal variations in body weight at weaning were also a contributory factor in determining the age of first vaginal oestrus. Covariance analyses revealed that, even after adjustment of the treatment means for the seasonal differences in body weight, there were significant effects on the age of puberty due to seasonal shifts in recipient sensitivity, but not with respect to the month in which the urine was collected.
\end{abstract}

\section{Introduction}

There are at least four substances in mouse urine that influence the timing of sexual development in conspecific females. Urine from male mice, from female mice in oestrus and from female mice that are pregnant or lactating all accelerate sexual maturation in young females, whereas the urine of females caged in groups delays the onset of puberty in other females (Vandenbergh, 1969; Vandenbergh et al., 1972; Drickamer, 1974, 1986a; Drickamer \& Hoover, 1979). Seasonal variations in the effectiveness of the urinary chemosignals influencing the timing of puberty have been reported by several investigators using different measures of sexual development (Vandenbergh et al., 1975; Drickamer, 1977, 1984a; Bronson, 1979). In general it has been difficult to accelerate puberty during the winter months and, conversely, it has been difficult to delay puberty in the summer months. Tests conducted during spring and fall months produce mixed results.

These observed differences could be due to variations in the potency of the urinary chemosignals from the donor mice or to differences attributable to month-to-month variations in the sensitivity of the young female recipient mice to the chemosignals. It is also possible that some form of interaction could occur between any seasonal variations in chemosignal quality and recipient sensitivity. There may also be variation depending upon which chemosignal is being investigated. The present experiments examined donor chemosignal quality and recipient sensitivity for three of the urinary chemosignals, male urine, urine from pregnant or lactating females, and urine from females housed in groups.

\section{Materials and Methods}

The mice used in these experiments were from a randomly-bred closed-colony of ICR/Alb house mice (Mus musculus). All colony and test mice were housed in standard polypropylene cages measuring $15 \times 28 \times 15 \mathrm{~cm}$ with opaque sides 
and fitted wire lids containing a food hopper and an opening for the water bottle. Bedding of ground wood shavings was changed once per week. Purina Mouse Chow and water were supplied ad libitum throughout the experiments. Colony and experimental rooms were maintained at $21-25^{\circ} \mathrm{C}$ and $30-70 \%$ relative humidity on a $12 \mathrm{~h}$ light $/ 12 \mathrm{~h}$ dark daily regimen with overhead fluorescent lights on from $06: 00 \mathrm{~h}$ to $18: 00 \mathrm{~h}$.

Design. A $6 \times 6$ cross-classified experimental design was used to test for seasonal variations in the quality of urinary chemosignals and the sensitivity of female recipients. The same design was used for each of the three urinary chemosignals tested, male urine, urine from females that were pregnant or lactating and urine from females housed in groups. During Year 1 urine collection procedures were carried out every other month, January, March, May, July, September and November, In Year 2 young female mice were tested in the same sequence of alternate months. At each test month, groups of individually caged young females were treated with urine from each of the different collection months. Ten mice were treated with urine from each collection month for each of the chemosignals. There were therefore 6 collection months and 6 treatment months with 10 females tested in each of the 36 cells of the design and the design was repeated once for each of the three chemosignal types.

Collection. Urine collection during Year 1 was conducted in the alternate months specified above. For male urine the donors were intact, adult (90-180 days of age) males, with no prior sexual experience, housed 3 per cage. For females that were pregnant or lactating urine was collected from individually caged, adult (80-200 days of age) primparous females or adult ( $90-210$ days of age) primparous females that were housed with their litters. Urine was collected only during the last 10 days of gestation as determined by detection of vaginal plugs at insemination or during the last 10 days of lactation as determined from the date of parturition (see Drickamer, 1983a). For urine from females housed in groups, the donors were adult (100-200 days of age) primiparous females that had been housed 7 or 8 per cage for at least 20 days before urine collection (see Drickamer, 1982a, 1983b; Coppola \& Vandenbergh, 1985).

Urine was collected over a 4-6-day period near the middle of each specified month. Urine collection was carried out between 06:00 and 09:00 h, a time when chemosignals from each of the three donor types have been previously shown to be present in the urine in quantities sufficient to produce the characteristic acceleration or delay of puberty (Drickamer, 1982b, 1984b). Urine was collected by holding the donor mice over a Petri dish and gently squeezing the flanks. In this manner 3-4 ml urine were collected each day from the 40-60 donors available of each type. This quantity was subdivided into samples $(0.3 \mathrm{ml})$ placed in small, labelled glass vials and stored at $-40^{\circ} \mathrm{C}$ until needed for treatment. When a sufficient number of vials had been accumulated for that month for each urine donor type the procedure was terminated until the next designated collection month. Separate Petri dishes were used for each type of urine and new sets of dishes were used at each collection month.

Treatment females. To produce young females for the prescribed months of testing in Year 2, pregnant females mice were isolated into individual cages during the last week before parturition. All cages were then checked daily and births were recorded. On the day after birth each litter was counted and all the young were sexed. Each litter was reduced to exactly 10 young, including at least 3 male young. Litters of less than 10 young were discarded. Mice were weaned 21 days after birth and were immediately assigned at random to a particular treatment. Each mouse was examined daily from Day 21 until the occurrence of vaginal introitus. Starting on the day of vaginal introitus, a vaginal lavage was taken each day until the occurrence of first vaginal oestrus. The wet-mount vaginal smears were examined immediately with a light microscope and the cellular contents were judged, by estimating the numbers of leucocytes and cornified epithelial cells present, to determine the stage of the oestrous cycle according to the criteria of Rugh (1968) and Vandenbergh et al. (1972), i.e. 90-100\% cornified cells. During the course of the year in which mice were treated and tested. 7 different individuals were involved in taking the daily vaginal lavages; 4 of these individuals were not aware of the details of the experiment and 3 were aware of the treatments. Inter-observer reliability tests involving pairwise comparisons among 5 of these 7 persons resulted in correlation values ranging from 0.94 to 1.00.

Each test mouse was weighed to the nearest $0.1 \mathrm{~g}$ on the day of weaning. These body weights were analysed to determine whether there were any seasonal differences in weaning weight that might contribute to any observed variations in age of puberty.

Each test mouse was treated daily for 14 days starting on the day of weaning by painting the prescribed urine on the external nares using $3-4$ strokes of a small paintbrush. In this manner about $0.05 \mathrm{ml}$ urine is transferred daily to the nares; this is a sufficient quantity to induce acceleration or delay of puberty (Drickamer, 1982c, 1974c) and using more than $0.05 \mathrm{ml}$ urine results in most of the urine running off the nose. A separate vial was opened each day for each urine source and each collection month and all of the vials were discarded after the urine treatment procedure for that day. All urine treatments were conducted between 06:00 and 09:00 h, a time that has proved successful for treatment with urine from all three donor types (Drickamer, 1982b, 1984b). Also, the daily checks for vaginal introitus and all vaginal smears were conducted during that same time period each day.

\section{Results}

Two-way analyses-of-variance were conducted for each separate urine donor type. In each analysis the factor for month of urine treatment was significant (Table 1). In none of the analyses were the factors for month of urine collection (Table 2) or the interaction between month of urine collection 
Table 1. Mean ages in days ( \pm 1 s.e.m.) at first vaginal oestrus and mean body weights in $g( \pm 1$ s.e.m.) for 21 days of age in young female mice treated with 1 of 3 urine types during 1 of 6 months of the year

\begin{tabular}{|c|c|c|c|c|c|c|c|}
\hline \multirow[b]{2}{*}{ Month } & & \multicolumn{2}{|c|}{ Male urine } & \multicolumn{2}{|c|}{ Grouped female urine } & \multicolumn{2}{|c|}{ Pregnant/lactating female urine } \\
\hline & & First oestrus & Body weight & First oestrus & Body weight & First oestrus & Body weight \\
\hline Janu & & $32 \cdot 3(0 \cdot 4)^{\mathrm{c}}$ & $9 \cdot 6(0 \cdot 2$ & $39 \cdot 6(0 \cdot 5)^{\mathrm{c}}$ & $8 \cdot 8(0 \cdot 1)^{a}$ & $34 \cdot 3($ & $9.9(0.2)^{b}$ \\
\hline March & & $30.8(0.4)^{b}$ & $9 \cdot 3$ & $38 \cdot 3$ & $8 \cdot 8$ & $35.5(0.5)^{c, d}$ & $8.9(0 \cdot 1)^{\mathrm{a}}$ \\
\hline May & & $30 \cdot 9(0.4)^{\mathrm{b}}$ & $9.8(0.2)^{\mathrm{a}}$ & $36 \cdot 3(0.4)^{b}$ & $8 \cdot 6(0 \cdot 1)^{a}$ & $31 \cdot 4(0 \cdot 4)^{\mathrm{b}}$ & $8.9(0.1)^{\mathrm{a}}$ \\
\hline July & & $29.0(0.5)^{a}$ & $11 \cdot 1(0 \cdot 2)^{\mathrm{b}}$ & $34.3(0.6)^{\mathrm{a}}$ & $10 \cdot 3(0 \cdot 2)^{\mathrm{b}}$ & $29 \cdot 5(0.5)^{2}$ & $9 \cdot 9(0 \cdot 1)^{\mathrm{b}}$ \\
\hline September & & $29 \cdot 8(0 \cdot 4)^{\mathrm{a}, \mathrm{b}}$ & $11 \cdot 5(0 \cdot 3)^{\mathrm{b}}$ & $36.9(0.4)^{\mathrm{b}}$ & $11 \cdot 2(0 \cdot 2)^{\mathrm{b}}$ & $30 \cdot 6(0 \cdot 4)^{\mathrm{a}, \mathrm{b}}$ & $12 \cdot 2(0 \cdot 2)^{\mathrm{c}}$ \\
\hline November & & $34 \cdot 1(0 \cdot 4)^{d}$ & $9 \cdot 6(0 \cdot 2)^{a}$ & $39.8(0.5)^{c}$ & $9 \cdot 2(0 \cdot 1)^{a}$ & $36 \cdot 6(0 \cdot 5)^{d}$ & $9 \cdot 4(0 \cdot 2)^{\mathrm{a}, \mathrm{b}}$ \\
\hline & $\begin{array}{r}\mathbf{F}= \\
\text { d.f. }=\end{array}$ & $\begin{array}{c}18 \cdot 83 \\
5324 \\
P<0 \cdot 001\end{array}$ & $\begin{array}{c}22.28 \\
5324 \\
P<0.001\end{array}$ & $\begin{array}{c}18.48 \\
5324 \\
P<0.001\end{array}$ & $\begin{array}{c}49.60 \\
5324 \\
P<0.001\end{array}$ & $\begin{array}{c}40.44 \\
5324 \\
P<0.00 \mathrm{I}\end{array}$ & $\begin{array}{c}54 \cdot 19 \\
5324 \\
P<0.001\end{array}$ \\
\hline
\end{tabular}

F-ratios from analyses-of-variance and associated probabilities are given for the Treatment Factor from each analysis involving the 6 collection months $\times 6$ treatment months of the experimental design described in the text.

Those means in the same vertical column not marked by the same superscript letter are significantly different at $P<0.02$ by Duncan's New Multiple Range Test.

and month of urine treatment significant. A further breakdown of the mean ages of puberty for mice treated with male urine revealed an overlapping pattern of significant differences (Table 1) with males treated in July maturing significantly earlier than mice treated in any other month except September and mice treated in November maturing significantly later than all other months. For treatment with urine from grouped females, mice treated in November, January and March reached puberty significantly later than those treated in the other 3 months, and mice treated in July attained puberty earlier than those treated in May or September. For urine from pregnant or lactating females there was an overlapping pattern of significant differences with mice treated in July attaining puberty earlier than those in other months, except September, and mice treated in November reaching first oestrus later than those in any month except March. In general mice attained first oestrus earlier in summer months and later in winter months across all three types of urine treatment.

Separate two-way analyses-of-variance also revealed that there were significant differences in body weights at weaning; only the month of treatment factor was significant in these analyses (Table 1). There were no significant differences in weaning body weights for the month of collection main factor (Table 2), nor for the interaction factor. The patterns of significant differences across the treatment months (Table 1) show some degree of correspondence to the patterns of significant differences obtained for the mean ages of puberty, but there are numerous exceptions.

Because the analyses of body weights at Day 21 revealed consistent significant differences for the treatment factor it is possible that the results for mean ages of first vaginal oestrus are attributable to these weight differences and not to any seasonal variations affecting reproductive endocrinology. It was therefore necessary to conduct a separate covariance analysis for each of the urine source types (Table 3). In the course of each covariance analysis each of the main effects, month of collection and month of treatment, and the interaction factor, are adjusted for the effect of the covariate, body weight at 21 days of age, as the analysis proceeds. The three analyses all revealed similar findings. The covariate, as expected, was a significant factor and the month of treatment main factor also remained significant in each of the three analyses (Table 3). Neither the month of collection main factor nor the interaction factor were significant in any of the three analyses. A breakdown of the monthly means produced patterns of significant differences not distinguishable from those in Table 1. 
Table 2. Mean ages in days ( \pm 1 s.e.m.) at first vaginal oestrus and mean body weights in $g( \pm 1$ s.e.m. $)$ for 21 days of age in young female mice treated with 1 of 3 urine types collected during 1 of 6 months of the year

\begin{tabular}{|c|c|c|c|c|c|c|c|}
\hline \multirow[b]{2}{*}{ Month } & & \multicolumn{2}{|c|}{ Male urine } & \multicolumn{2}{|c|}{ Grouped female urine } & \multicolumn{2}{|c|}{ Pregnant/lactating female urine } \\
\hline & & First oestrus & Body weight & First oestrus & Body weight & First oestrus & Body weight \\
\hline \multirow{7}{*}{$\begin{array}{l}\text { January } \\
\text { March } \\
\text { May } \\
\text { July } \\
\text { September } \\
\text { November }\end{array}$} & & $30.9(0.4)$ & $10 \cdot 1(0 \cdot 2)$ & $37 \cdot 6(0 \cdot 4)$ & $9 \cdot 7($ & $33 \cdot 5(0 \cdot 5)$ & $10 \cdot 0$ \\
\hline & & $30 \cdot 7(0.5)$ & $10 \cdot 5(0 \cdot 2)$ & $36 \cdot 7(0.4)$ & $9 \cdot 5(0.2)$ & $32.8(0.4)$ & $10 \cdot 1(0 \cdot 2)$ \\
\hline & & $31.8(0.5)$ & $10 \cdot 0(0 \cdot 2)$ & $37.7(0.5)$ & $9 \cdot 6(0 \cdot 2)$ & $32.4(0.4)$ & $9 \cdot 6(0 \cdot 2)$ \\
\hline & & $31.6(0.5)$ & $9 \cdot 5(0 \cdot 3)$ & $37.9(0.5)$ & $9 \cdot 4(0 \cdot 2)$ & $33.4(0.4)$ & $9.9(0.2)$ \\
\hline & & $30 \cdot 9(0 \cdot 4)$ & $10 \cdot 3(0 \cdot 3)$ & $37.2(0.4)$ & $9 \cdot 3(0 \cdot 2)$ & $32 \cdot 6(0 \cdot 3)$ & $10 \cdot 0(0 \cdot 2)$ \\
\hline & & $30 \cdot 9(0 \cdot 5)$ & $10 \cdot 0(0 \cdot 2)$ & $37 \cdot 1(0 \cdot 3)$ & $9 \cdot 4(0 \cdot 2)$ & $33 \cdot 8(0 \cdot 5)$ & $9 \cdot 6(0 \cdot 2)$ \\
\hline & $\begin{array}{r}F= \\
\text { d.f. }=\end{array}$ & $\begin{array}{c}1.01 \\
5324 \\
P>0.40\end{array}$ & $\begin{array}{c}0.71 \\
5324 \\
P>0.40\end{array}$ & $\begin{array}{c}0.90 \\
5324 \\
P>0.40\end{array}$ & $\begin{array}{c}0.97 \\
5324 \\
P>0.40\end{array}$ & $\begin{array}{c}0.91 \\
5324 \\
P>0.40\end{array}$ & $\begin{array}{c}0.91 \\
5324 \\
P>0.40\end{array}$ \\
\hline
\end{tabular}

F-ratios from analyses of variance and associated probabilities are given for the Collection Factor from each analysis involving the 6 collection months $\times 6$ treatment months of the experimental design described in the text.

Table 3. Analyses-of-covariance for chemosignal effects on first vaginal oestrus in young female mice using urine from (a) males, (b) grouped females or (c) pregnant or lactating females, with body weight at Day 21 of age as a covariate

\begin{tabular}{|c|c|c|c|c|c|}
\hline $\begin{array}{l}\text { Urine } \\
\text { source }\end{array}$ & Factor & d.f. & Mean Square & F-ratio & Significance \\
\hline \multirow[t]{6}{*}{ Males } & $\begin{array}{l}\text { Covariate } \\
\text { Body weight Day } 21 \\
\text { Main effects }\end{array}$ & 1 & $702 \cdot 63$ & $73 \cdot 22$ & $P<0.001$ \\
\hline & Month of urine collection & 5 & $8 \cdot 49$ & 0.88 & $P>0.40$ \\
\hline & Month of urine treatment & 5 & $123 \cdot 83$ & $12 \cdot 90$ & $P<0.001$ \\
\hline & $\begin{array}{l}\text { Interaction } \\
\text { Collection } \times \text { Treatment }\end{array}$ & 25 & $7 \cdot 36$ & 0.77 & $P>0.40$ \\
\hline & Error & 323 & 9.60 & & \\
\hline & Total & 359 & $(S S=4646.60)$ & & \\
\hline \multirow{8}{*}{$\begin{array}{l}\text { Grouped } \\
\text { females }\end{array}$} & Covariate & & & & \\
\hline & Body weight Day 21 & 1 & $378 \cdot 60$ & 26.55 & $P<0.001$ \\
\hline & Main effects & & & & \\
\hline & Month of urine collection & 2 & 1.35 & 0.11 & $P>0.40$ \\
\hline & Interaction & & & & \\
\hline & Collection $\times$ Treatment & 25 & $14 \cdot 48$ & $1 \cdot 02$ & $P>0.40$ \\
\hline & Error & 323 & $14 \cdot 26$ & & \\
\hline & Total & 359 & $(\mathrm{SS}=6437.90)$ & & \\
\hline \multirow{9}{*}{$\begin{array}{l}\text { Pregnant/ } \\
\text { lactating } \\
\text { females }\end{array}$} & & & & & \\
\hline & Covariate & & & & \\
\hline & Body weight Day 21 & 1 & $559 \cdot 91$ & $45 \cdot 60$ & $P<0.001$ \\
\hline & Main effects & & & & \\
\hline & Month of urine collection & 5 & $11 \cdot 38$ & 0.93 & $P>0.40$ \\
\hline & $\begin{array}{l}\text { Month of urine treatment } \\
\text { Interaction }\end{array}$ & 5 & $420 \cdot 76$ & $34 \cdot 26$ & $P<0.001$ \\
\hline & Collection $\times$ Treatment & 25 & $10 \cdot 12$ & 0.82 & $P>0.40$ \\
\hline & Error & 323 & $12 \cdot 28$ & & \\
\hline & Total & 359 & $(\mathrm{SS}=6942 \cdot 53)$ & & \\
\hline
\end{tabular}




\section{Discussion}

The foregoing experiments and analyses indicate that both the sensitivity of the young female mice to the urinary chemosignals and the body weights of the mice at the time of weaning ( 21 days) vary seasonally and both factors contribute to observed differences in the age of first vaginal oestrus across the months of the year. Further, covariance analysis, using body weight at 21 days of age as the covariate, revealed that even when the data for first oestrus are adjusted for the effects of the weaning body weights, the mice still exhibit significant seasonal shifts in sensitivity to the urinary chemosignals.

The patterns of significant variation were quite similar for each of the three different types of urine tested. Further, while there are clearly some relationships between body weight, chemosignal sensitivity and the timing of sexual development, the weight factor and chemosignal influence appear to operate independently of one another, at least at some seasons of the year. An examination of the mean values in Table 1 reveals that, for male urine, earlier puberty occurred in both March and May in spite of the fact that the body weights at Day 21 were significantly lighter than for July and September, the other two months in which accelerated puberty occurred under the influence of the male urinary substance. Similarly, for grouped females puberty was delayed by chemosignal treatment in May and September relative to July, although the body weight at 21 days in May was significantly lighter than for July or September. Also, for treatment with urine from pregnant or lactating females there were overlapping patterns of significant differences for body weight at 21 days of age and for the sensitivity to the chemosignal treatment, further exemplifying that the body weight and chemosignal effects are, in some circumstances, independently affecting the programme for sexual development.

There are apparently no seasonal changes in the quality of any of the three urinary chemosignals tested; each urine source produced the expected delay or acceleration in the same manner throughout the year. This finding makes sense if the various urinary chemosignals are believed to be metabolites of or indirect by-products formed under the influence of various endocrine substances in the mice (see Vandenbergh, 1983; Drickamer, 1986b). Male and female mice are reproductively active throughout the year in the laboratory and would thus be producing the urinary chemosignals. It would be most interesting to investigate these seasonal effects in a species that exhibits a clear seasonal rhythm in reproductive activity; preferably a species that breeds for a portion of the year and does not breed at all for the remainder of the year. In such circumstances I would expect that, in contrast to the findings reported here, there would be seasonal shifts in the sensitivity of recipient females to the urinary substances and some definite changes in quantity and/or quality of the urinary signals released by donor animals.

The observed shifts in sensitivity to the urinary chemosignals that accelerate or retard sexual development in the mice are probably keyed, through natural selection, to the existence of particular environmental conditions. A mouse reaching puberty and starting to reproduce in the winter months might well lose the litter(s) conceived and could suffer in terms of nutritional needs and general health in a manner sufficient to significantly reduce her fitness. She might also lose sufficient energy so as to reduce future reproductive efforts, even when conditions are more favourable and thus further lower her fitness. By delaying the response to puberty-accelerating signals until the more probable existence of favourable environmental conditions, a female could greatly enhance her total reproductive output.

In some geographical locations the existence of conditions favourable for successful reproduction do not necessarily coincide with the seasons. Under such conditions fewer constraints would be imposed on the responsiveness of females to the urinary chemosignals. To date all aspects of these urinary chemosignal systems that have been tested using wild stocks and feral populations of Mus musculus provide results that are in close agreement with the findings reported for laboratory mice (Bronson, 1979; Drickamer, 1979, 1984d, e; Massey \& Vandenbergh, 1980, 1981). It would therefore be most interesting to explore, in a comparative fashion, the responsiveness of wild $\mathrm{Mus}$ 
musculus from a variety of habitats and geographical locations to the various urinary chemosignals that influence reproductive condition.

This research was supported in part by United States Public Health Service Grant No. HD-08585. I thank Susan Sohler, Jeffrey Roth, Lori Symanski, Jane Roberts, Niels Oleson and Craig Blackmore for their assistance with some phases of the data collection portion of this project.

\section{References}

Bronson, F.H. (1979) The reproductive ecology of the house mouse. Quart. Rev. Biol. 54, 262-299.

Coppola, D.M. \& Vandenbergh, J.G. (1985) Effect of density, duration of grouping and age of urine stimulus on the puberty delay pheromone in female mice. J. Reprod. Fert. 73, 517-522.

Drickamer, L.C. (1974) Sexual maturation of female mice: social inhibition. Devl Psychobiol. 7, 257-265.

Drickamer, L.C. (1977) Delay of sexual maturation in female house mice by exposure to grouped females or urine from grouped females. J. Reprod. Fert. 51, $77-81$

Drickamer, L.C. (1979) Acceleration and delay of first vaginal estrus in wild Mus musculus. J. Mammal. 60, $215-216$

Drickamer, L.C. (1982a) Delay and acceleration of puberty in female mice by urinary chemosignals from other females. Devl Psychobiol. 15, 433-442.

Drickamer, L.C. (1982b) Acceleration and delay of sexual maturation in female mice via chemosignals: circadian rhythm effects. Biol. Reprod. 27, 596-601.

Drickamer, L.C. (1982c) Acceleration and delay of first vaginal oestrus in female mice by urinary chemosignals: dose levels and mixing urine treatment sources. Anim. Behav. 30, 456-460.

Drickamer, L.C. (1983a) Chemosignal effects on puberty in young female mice: urine from pregnant and lactating females. Devl Psychobiol 16, 207-217.

Drickamer, L.C. (1983b) Effects of period of grouping of donors and duration of stimulus exposure on delay of puberty in female mice by a urinary chemosignal from grouped females. J. Reprod. Fert. 69, 723-727.

Drickamer, L.C. (1984a) Seasonal variation in acceleration and delay of sexual maturation in female mice by urinary chemosignals. $J$. Reprod. Fert. 72, 55-58.

Drickamer, L.C. (1984b) Acceleration of puberty in female mice by a chemosignal from pregnant and lactating females: circadian rhythm effects. Biol. Reprod. 31, $104-108$.

Drickamer, L.C. (1984c) Effects of very small doses of urine on acceleration and delay of sexual maturation in female house mice. J. Reprod. Fert. 71, 475-477.
Drickamer, L.C. (1984d) Acceleration of puberty by a urinary chemosignal from pregnant and lactating Mus musculus. J. Mammal. 65, 697-699.

Drickamer, L.C. (1984e) Urinary chemosignals from mice (Mus musculus): acceleration and delay of puberty in related and unrelated young females. $J$. comp. Psychol. 89, 414420.

Drickamer, L.C. (1986a) Effects of urine from females in oestrus on puberty in female mice. J. Reprod. Fert. 77, 613-622.

Drickamer, L.C. (1986b) Puberty-influencing chemosignals in house mice: ecological and evolutionary considerations. In Chemical Signals in Vertebrates, Vol. 4, pp. 441-455. Eds D. Duvall, D. MüllerSchwarze \& R. M. Silverstein. Plenum Publishing, New York.

Drickamer, L.C. \& Hoover, J.E. (1979) Effects of urine from pregnant and lactating female house mice on sexual maturation of juvenile females. Devl Psychobiol. 12, 545-551.

Massey, A. \& Vandenbergh, J.G. (1980) Puberty delay by a urinary cue from female house mice in feral populations. Science, N.Y. 209, 821-822.

Massey, A. \& Vandenbergh, J.G. (1981) Puberty acceleration by a urinary cue from male mice in feral populations. Biol. Reprod. 24, 523-527.

Rugh, R. (1968) The Mouse, Its Reproduction and Development. Burgess Publishing Co., Minneapolis.

Vandenbergh, J.G. (1969) Male odor accelerate female sexual maturation in mice. Endocrinology 84, $658-660$.

Vandenbergh, J.G. (1983) Pheromonal regulation of puberty. In Pheromones and Reproduction in Mammals, pp. 95-112. Ed. J. G. Vandenbergh. Academic Press Inc., New York.

Vandenbergh, J.G., Drickamer, L.C. \& Colby, D.R. (1972) Social and dietary factors in the sexual maturation of female mice. J. Reprod. Fert. 28, 397-405.

Vandenbergh, J.G., Whitsett, J.M. \& Lombardi, J.R. (1975) Partial isolation of a pheromone accelerating puberty in female mice. $J$. Reprod. Fert. 43, 515-523.

Received 30 September 1986 